\title{
Comparison of Post-harvest Practices of the Individual Farmers and the Farmers in Cooperative of Côte d'Ivoire and Statistical Identification of Modalities Responsible of Non-quality
}

\author{
Djedjro C. Akmel ${ }^{1}$, Arsène. L. I Nogbou ${ }^{1}$, Ibrahima Cissé ${ }^{1}$, Kouassi E. Kakou ${ }^{1}$, Kisselmina Y. Koné ${ }^{1}$, Nogbou E \\ Assidjo $^{1}, \&$ Benjamin Yao ${ }^{1}$ \\ ${ }^{1}$ Laboratoire des Procédés Industriels, de Synthèses, de l'Environnement et des Energies Nouvelles, Institut \\ National Polytechnique Félix Houphouet Boigny (LAPISEN/ INP-HB), Yamoussoukro, Côte d'Ivoire \\ Correspondence: Djedjro C. Akmel, Laboratoire des Procédés Industriels, de Synthèses, de l'Environnement et \\ des Energies Nouvelles, INP-HB, BP 1313 Yamoussoukro, Côte d'Ivoire. E-mail: akmeldc@ gmail.com
}

Received: October 12, 2016

Accepted: October 31, 2016 Online Published: November 19, 2016

doi:10.5539/jfr.v5n6p102

URL: http://dx.doi.org/10.5539/jfr.v5n6p102

\begin{abstract}
The purposes of this study were to compare the modalities of the post-harvest practices of these two groups and to statistically identify the modalities responsible of non-quality (under grade) on the basis of results of Pareto chart and proportion of successes calculated for each modality. A survey about of modalities of post-harvest processing methods and about the quality of the beans obtained was conducted among producers of the largest producing region of Côte d'Ivoire. The collected data were analyzed by the chi-square test of concordance and the Pareto chart. The results show that there is no correlation between practice of the individual farmers and the farmers in cooperatives. Highly significant differences (p-value < 0.001) were observed in the number of brewing; the fermentation time; the materials of fermentation and drying impacting the quality of merchantable cocoa. Samples collected from farmers into cooperatives have fewer defects than those of individual farmers. Regarding the modalities of the post-harvest practice responsible of the under-grades, the results showed that the samples of farmers in cooperatives had fewer defects than those of individual farmers. Thus, obtaining a good quality cocoa beans must take into account the best modality at each step of post-harvest practices. However certain modality should be avoided. These are: the time breaking pods of one day; the absence of brewing during the fermentation; the time of fermentation less than or equal to three days and the time of drying less than or equal to two days.
\end{abstract}

Keywords: modalities, post-harvest practices, merchantable cocoa, Pareto chart, chi square test, proportion of successes

\section{Introduction}

The economy of some countries is largely based on the export of cocoa. This is the case of Côte d'Ivoire, the world's largest cocoa grower, with a production of the order of 1.78 million tons or $40 \%$ of world supply (Anonymous, 2015). Its production represents 15\% of GDP (Gross Domestic Product) and 30\% of export earnings (Koko, 2014).

Although Côte d'Ivoire recorded spectacular results at the quantity level, the results are below expectations at the quality level. Indeed, in recent years, and following liberalization occurred in 1999, we noticed a recurring situation of bad quality cocoa from Côte d'Ivoire on the world market (Anonymous, 2006). The free fatty acid content from Côte d'Ivoire's cocoa exceeds standards allowed $1.75 \%$, which has meant the decline in its quality (Guéhi et al., 2005). In addition, a portion of national production is stored poorly and has a humidity above the standard (more than 8\%). This situation is growing and causes the discount of the cocoa from Côte d'Ivoire, what constitutes a financial loss for the producers. The causes for the decreasing of the quality of cocoa are not sufficiently identified. They appear to be multiple and complex and are at all levels of the collection and distribution chain, from producer to foreign markets (Anonymous, 2006). However, some causes have been mentioned for this decreasing. It comes to the inefficient system of quality control of the products; internal marketing system and external difficult to control; unprofessionalism of some producers and the deterioration of the products in farms (Anonymous , 2006; Anonymous , 2016). But of all these causes, the most significant are 
the post-harvest practices because they are preliminary and decisive step in the transformation of the merchantable cocoa. A bad post-harvest treatment may rot or germinate cocoa beans, which reduces the quality of merchantable cocoa (Janny, Ritchie, \& Flood, 2003). According Barel (2013), "Everything is happening in the post-harvest treatment of cocoa! Each cocoa has a potential intrinsic quality which depends on the variety of trees planted, the soil and the know-how of agricultural planter. But this potential can be valorized or deteriorated during the post-harvest pratices."

In Côte d'Ivoire, all post-harvest practices are managed by two groups of producers: farmers organized in cooperatives since the cooperative law of 1997 and the small individual farmers. The farmers' cooperatives receive technical support from the Government, NGOs or Western chocolatiers.

In these cooperatives, there are sometimes large farms whose area may approach 50 ha. The current tendency of producers is to increase acreage to compensate for falling prices (Banzio, 2003; N'Guessan, 2004). Some cooperatives also have many opportunities that can be the direct export of cocoa; guarantees in terms of marketing products; accessibility to additional services such as laboratory for quality control and computer equipment with software for managing. These cooperatives sell about 20 to $30 \%$ of national production.

In addition to the cooperatives, there are about 3 to 4 million people working in the cocoa chain and coffee in Côte d'Ivoire. This is usually small independent cocoa farmers and coffee, with mostly family farms ranging in size from 4 to 5 ha on average. These deliver their produce to buyers or subcontractors and trackers. It is estimated that one hectare of cocoa plantation can naturally produce 1.5 tons of cocoa beans. For now in Côte d'Ivoire, one hectare of cocoa produces on average 400 to $500 \mathrm{~kg}$ (Anonymous, 2010).

The responsibility of individual farmers and the farmers' cooperatives is significant in the search for the quality. Indeed, they must follow the cultural itinerary adapted and advised by farm advisors to appropriately perform the harvest and post-harvest practices namely fermentation and drying which are crucial steps that influence the final quality of the cocoa. However, at each step of post-harvest practices, several choices of modalities are available to both producer groups. Is there a significant difference between these two groups from the modalities of post-harvest practices? Many studies have shown the impact of the post-harvest processing methods on quality of merchantable cocoa (Cros \& Jeanjean; 1995; Lainé, 2001; Mounjouenpou et al., 2011; Barel, 2013; Levai, Meriki, Adiobo, Awa-Mengi \& Akoachere, 2015). However, none of them evaluated quantitatively the effects of each producer group on quality. And the quantitative influence of the modalities used by the producers is not known about the quality of cocoa. It is therefore with good reason this study was conducted.

The main purposes of this work were firstly to compare the modalities of post-harvest processing methods of these two groups, and secondly to statistically identify the modalities responsible of non-quality (under grade) of merchantable cocoa on the basis of results of Pareto chart and proportion of successes calculated for each modality.

\section{Material and Methods}

\subsection{Material}

The material was composed of 90 samples of merchantable cocoa of the Forastero variety. These samples were purchased from producers of seven production areas of the Soubre region which is also the first cocoa-producing among the regions in Côte d'Ivoire. The collection of samples was carried out during the great cocoa campaign 2013.

\subsection{Methods}

\subsubsection{Sampling for the Comparison of Post-harvest Practices}

Data collection was performed using a digital questionnaire which allowed to identify different forms of post-harvest practices of individual farmers and the farmers' cooperatives. A simple random sample of 30 farmers was selected by area (Table 1). Using the direct questionnaire during individual interviews, each producer gave information about its post-harvest practices. In total, 210 cocoa farmers were surveyed in 31 villages. 
Table 1. Visited areas and number of farmers in the study

\begin{tabular}{llll}
\hline Sub-prefectures of Soubré & areas of production & Number of village & Number of farmers surveyed \\
\hline Oupoyo & Petit Bondoukou & 3 & 30 \\
Méagui & Kragui & 7 & 30 \\
& Krohon & 6 & 30 \\
Okrouyo & Ottawa & 4 & 30 \\
& Kouamékro & 4 & 30 \\
Guéyo & Bobouo & 3 & 30 \\
& Djenandou & 4 & 30 \\
Total & & 31 & 210 \\
\hline
\end{tabular}

2.2.2 Identification of Modalities of the Post-Harvest Practices Responsible for the Non-Quality (Under Grade)

\subsubsection{Sampling}

Taking into account the results of the survey, a stratified sampling plan based on the modalities of the fermentation equipment's (Banana Leaves; black plastic films; nylon tarps) allowed to classify the types of producer (Table 2).

Table 2. Sampling plan

\begin{tabular}{llll}
\hline Group of producers & Modalities of the fermentation & Number of samples & Total \\
\hline \multirow{3}{*}{ Individual farmers } & Banana leaves; & 15 & \\
& Black plastic films & 15 & 45 \\
& Nylon tarps & 15 & \\
Farmers in cooperatives & Banana leaves; & 15 & 45 \\
& Black plastic films & 15 & \\
General total & Nylon tarps & 15 & 90 \\
\hline
\end{tabular}

At each group of producers 45 samples of $1 \mathrm{~kg}$ were taken because of 15 samples by fermentation method. Each sample was weighed with a dial dynamometer spring from Ducatillon brand and packaged in a food bag jute of size $30 \mathrm{~cm} / 40 \mathrm{~cm}$. For each sample, the time for breaking cocoa pods, the number of brewing during fermentation, the fermentation time, the fermentation materials, the drying time and the drying materials were noted.

\subsubsection{Sample Classification Based on International Standard}

\subsection{Humidity}

Post-harvest practices traceability of samples was carried out only for those whose average humidity level were less than $8 \%$. The Humidity of the cocoa beans has been measured on the 90 samples with a moisture meter from Dickey John "mini GAC plus" brand.

\subsection{Cut Test}

The cocoa beans of each sample underwent a mixing. One hundred beans were counted then cut longitudinally with a bean guillotine (Barel, 2013). Examination of cocoa beans was done in the light of day when the weather was clear (International trade centre [UNCTAD/WTO], 2001). The cocoa beans with several defaults were classified in the same category of defects (moldy, moth-eaten or slate) according to the international standard for cocoa export.

2.2.2.3 Construction of Pareto Chart for Under-Grades and Determination of Proportion of Successes (Grade I and Grade II) for Each Modality

On the basis of surveys conducted, the traceability of the 90 samples (the modalities applied and quality obtained) according to the international standard was known. It was possible to construct Pareto chart for under-grades and to determine of proportion of successes (grade I and grade II) for each modalitiy.

\subsection{Construction of Pareto Chart}

The Pareto chart has allowed to better identify the modalities of post-harvest responsible for $80 \%$ of all non-quality observed. The construction of the Pareto chart was first to determine the modalities which have resulted in a non-quality samples. Then, for each post-harvest practice, the number of observations for the 
modalities was ranked in descending order of their size by histogram. For the equal sizes, the modality unadvised according to experts or literature was chosen first. Finally, the modalities that cumulated size were more than $80 \%$ have been identified as responsible for the poor quality.

\subsection{Determination of Proportion of Successes}

The proportion of successes (PS) was determined for each modality. It is the percentage of each modality leading to the quality samples (grade I or grade II). It was determined as following:

$$
P S(\%)=\frac{\text { Numberofobservationsforthemodalityleadingthequalitysamples } \times 100}{\text { Totalnumberofobservationsforthemodality }}
$$

\subsection{Statistical Analyses}

Data analysis, figures and Pareto charts were done using the softwares Microsoft Office Excel 2010 and Statistica 7.1. The chi square test was performed to verify the similarity of post-harvest practices between the two groups of producers at significance levels of $0.05,0.01$ and 0.001 .

\section{Results and Discussion}

\subsection{Results}

\subsubsection{Comparison of Post-harvest Practices}

\subsubsection{Time for Breaking Pods}

The survey conducted among producers, shows that the time breaking pods varies between 1 and 15 days (figure 1) with distributions of both producer groups significantly similar according the chi square test (p-value $>0.05$ ) ( table 3). The modalities of the time for breaking pods change little from one type of group to another. The modalities for 2 to 7 are represented with $93 \%$ and $90 \%$ by most conditions individual farmers and farmers' cooperatives respectively. The other modalities are either absent or marginally represented. Furthermore, the area harvested seems to increase with the time breaking pods particularly between 1 and 7 day (Figure 1).

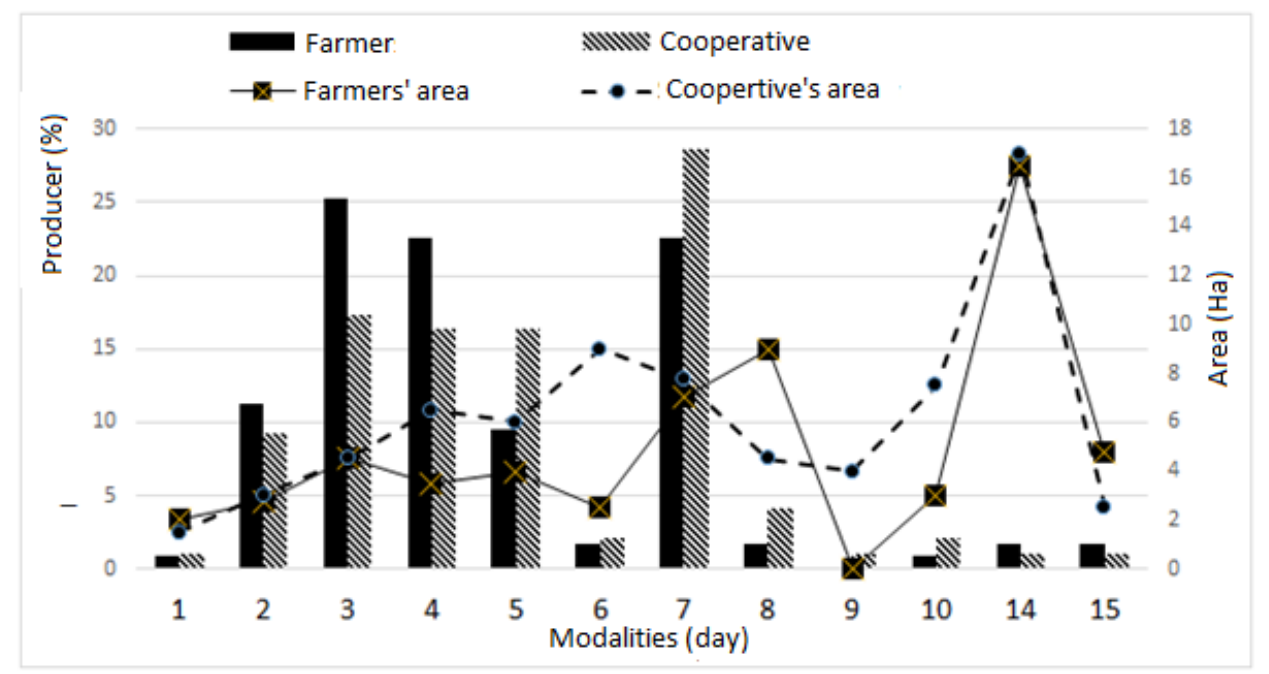

Figure 1. Comparisons of Time breaking cocoa pods and area harvested

Table 3. Chi-square tests of concordance for post-harvest practices

\begin{tabular}{llllllll}
\hline $\begin{array}{l}\text { Post-harvest } \\
\text { practices }\end{array}$ & $\begin{array}{l}\text { Time } \\
\text { breaking } \\
\text { cocoa pods }\end{array}$ & $\begin{array}{l}\text { Number } \\
\text { of } \\
\text { brewing }\end{array}$ & $\begin{array}{l}\text { Fermentation } \\
\text { time }\end{array}$ & $\begin{array}{l}\text { Equipment of } \\
\text { fermentation }\end{array}$ & $\begin{array}{l}\text { Drying } \\
\text { time }\end{array}$ & $\begin{array}{l}\text { Equipment } \\
\text { of drying }\end{array}$ & $\begin{array}{l}\text { Quality } \\
\text { (grades) }\end{array}$ \\
\hline p-value & 0.659 & $0.000^{*}$ & $0.000^{*}$ & $0.000^{*}$ & 0.478 & $0.000^{*}$ & $0.028^{*}$ \\
\hline
\end{tabular}

p-value gives the probability of accepting the concordance in the post-harvest practices between the individual farmers and the farmers' cooperatives. An asterisk $(*)$ indicates a significant difference $(\mathrm{p}<0.05)$, a highly significant differences $(p<0.01)$ or a very highly significant differences $(p<0.001)$ among the modalities of the post-harvest practices. 


\subsubsection{Number of Brewing}

The analysis of figure 2 shows that the distributions of the brewing modalities between the two groups of producer are different. According the chi square test (Table 2) this difference is very highly significant ( $\mathrm{p}$ value $<$ 0.001). Also the number of brewing varies inversely from individual farmers to farmers' cooperative (Figure 2). The most brewing modalities applied by farmers' cooperative is 2 to 3 brewings which represents $69 \%$ and 0 brewing for individual farmers which represents $26 \%$.

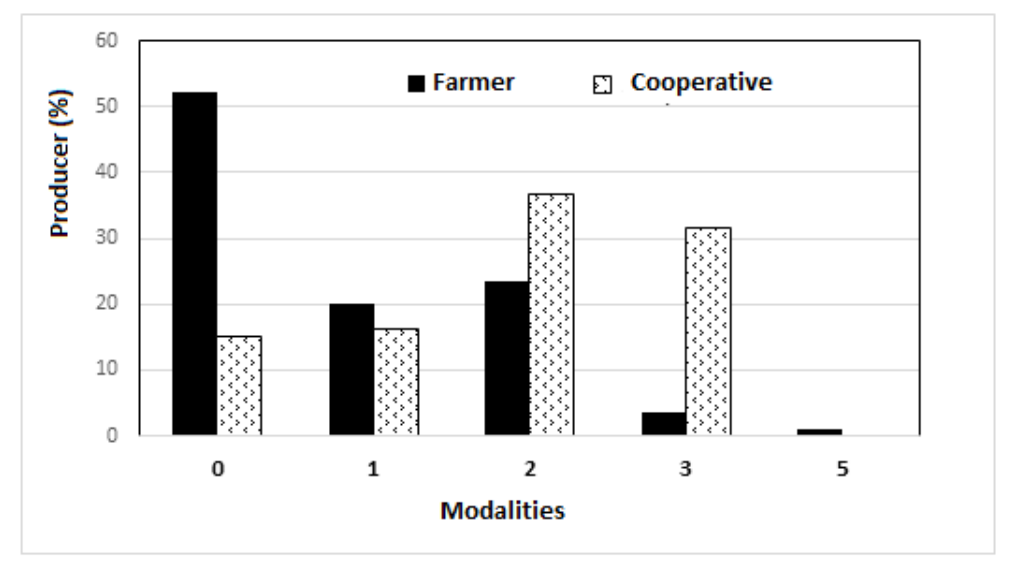

Figure 2. Comparisons of brewing during fermentation

\subsubsection{Fermentation Time}

The average time of fermentation for farmers' cooperative is higher than those for individual farmers. Indeed, $88 \%$ of farmers' cooperative conduct the fermentation in 6 or 7 days against 37\% among farmers (Figure 3). These observations are confirmed statistically with a p-value less than 0.001 showing a very highly significant difference of distributions of the modalities of fermentation times between the two groups of producer (Table 2). The recommended fermentation times (4 and 7 days) are carried out at $99 \%$ in farmers in cooperatives and $85 \%$ in individual farmers.

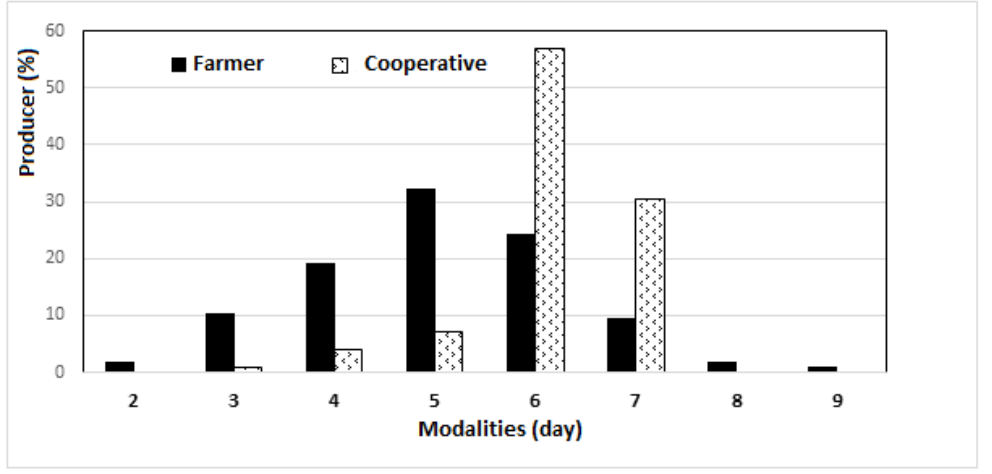

Figure 3. Comparisons of fermentation time

\subsubsection{Fermentation Materials}

The most commonly used fermentation materials are banana leaf, black plastic film and nylon tarp. They are used in $93 \%$ of cases by both groups of producers (Figure 4). However, 65\% of farmers in cooperatives mainly use the banana leaves (Figure 4). Instead, individual farmers use all types of equipment with $40 \%$ for black plastic film, $27 \%$ for the banana leaf and $26 \%$ for the nylon tarp. The results of the chi square test show that there a very highly significant difference ( $\mathrm{p}$ value $<0.001)$ between the two groups of producer $($ Table 3 ). 


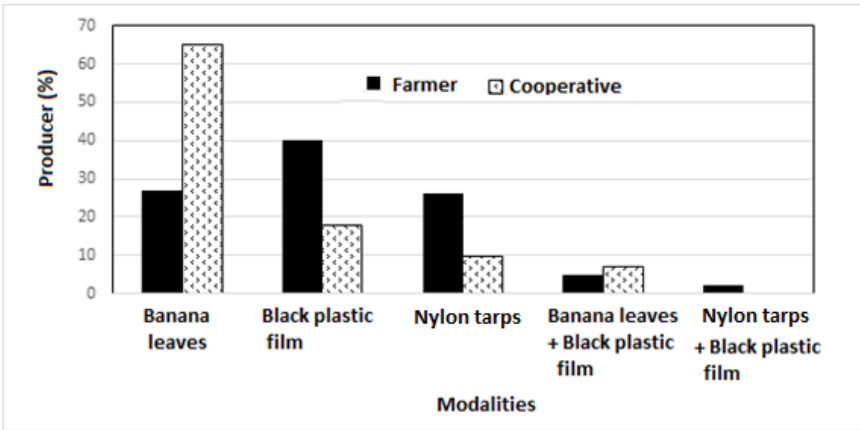

Figure4. Comparisons of fermentation materials

\subsubsection{Drying Time}

The distributions of drying time are similar for the both groups of producer (Figures 5). This observation was confirmed using the chi square test (p-value $>0.05$ ) (Table 2). However the modalities of drying time vary from 3 to 8 days for individual farmers and up to 10 days among farmers' cooperative. The predominant modality is 7 days for both groups of producer which corresponds to $37 \%$ of individual farmers and $36 \%$ of farmers' cooperative.

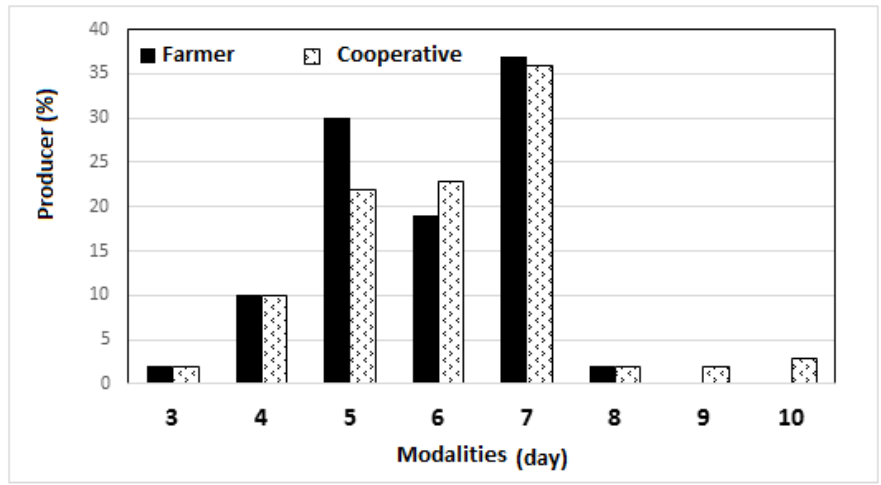

Figure 5. Comparisons of drying time

\subsubsection{Drying Materials}

The drying materials appear to be different for the both groups of producer (Figure 6). The proportion of using of the drying rack (recommended drying equipment) remains generally low among individual farmers (3\%) against $32 \%$ among farmers' cooperative. The predominant modality is nylon tarp with a proportion of 50\% and 39\% among individual farmers and farmers' cooperative respectively. The result of chi square test was very highly significant difference (Table 3). Thus Individual farmers use different drying equipment from those used by farmers in the cooperative.

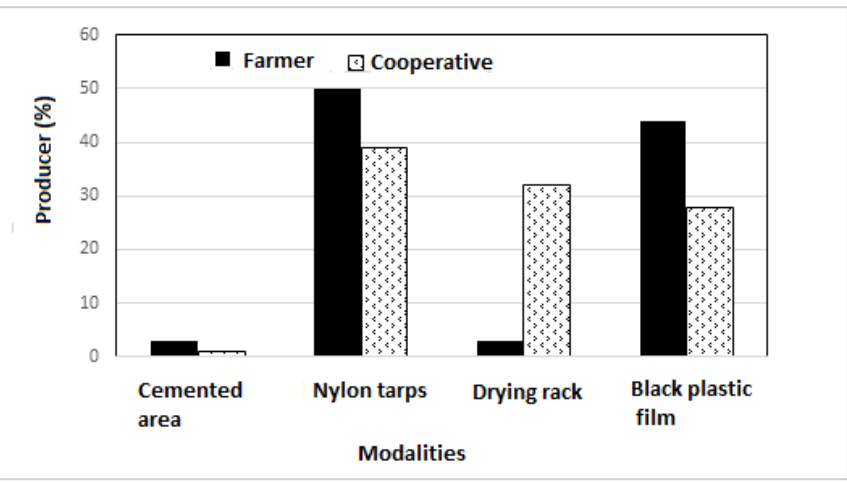

Figure 6. Comparison of drying equipment 


\subsubsection{Identification of Modalities of the Post-Harvest Practices Responsible for the Non-Quality (Under Grade)}

\subsubsection{Comparison of Different Quality Levels According to International Standard}

The figure 7 gives the comparison of different quality levels according to international standard. It also gives the effects of each producer group on each level of merchantable cocoa quality after post-harvest processing methods.

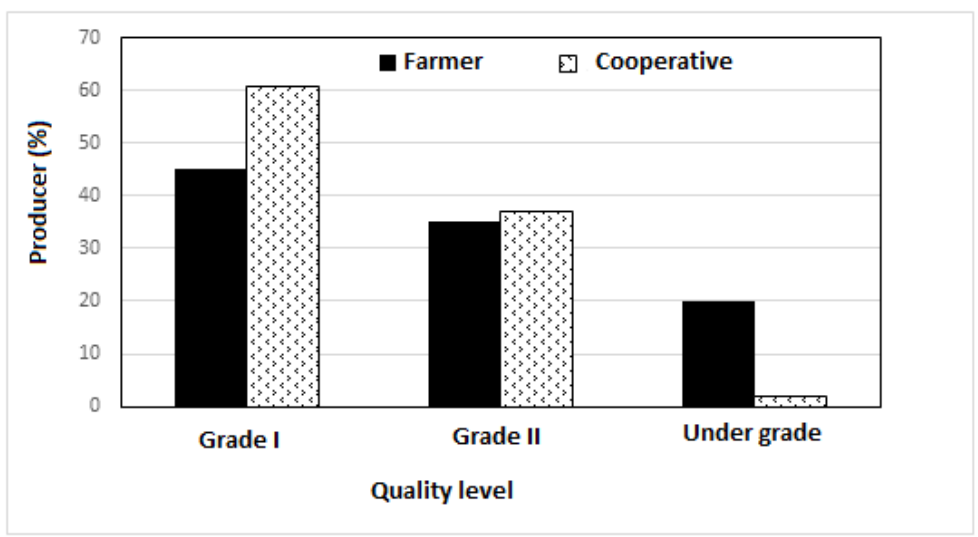

Figure7. Comparison of different quality levels according to international standard or effects of each producer group on cocoa quality

The samples from the farmers in cooperative are better than those collected from individual farmers (Figure 7). The chi square test shows a significant difference $(\mathrm{p}$-value $<0.05)$ in the quality of cocoa beans between the two groups of producers. Only $2 \%$ of the samples coming from farmers in cooperative were under grades against $20 \%$ of the samples from individual farmers (Figure7).

\subsubsection{Identification of the Time Breaking Cocoa Pods Causing Non-Quality}

The survey conducted among producers, shows in order of importance that the modalities of time breaking cocoa pods of 1 day (30\%); 3 days (20\%); 4 days (20\%) and 2 days (10\%) represent $80 \%$ of samples coming from non-qualities (under grade). The modalities of time breaking cocoa pods for 5 and 7 days represent $20 \%$ of under grades. No samples from the modalities of 6; 8; 12 and 14 days were under grade. According Figure 8B, more than $80 \%$ of each modality applied have achieved the quality samples except the modality of 1 day (less than $60 \%$ ). Also the comparison of these two figures (figure $8 \mathrm{~A}$ and $8 \mathrm{~B}$ ) seem to show a decreasing of the under grade (so the increasing of the quality) with the augmentation of time breaking cocoa pods.
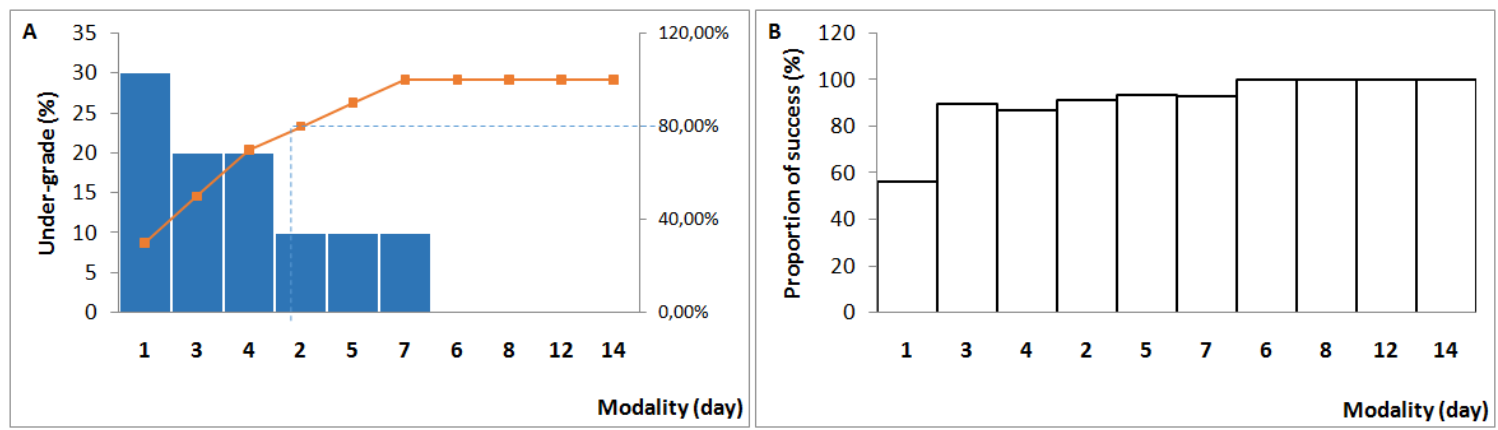

Figure 8. Time breaking cocoa pods (A: Pareto chart for modalities; B: Proportion of successes )

\subsubsection{Identification of Number of Brewing Causing Non-quality}

Eighty percent of samples in under grade are from the modalities of 0 and 2 brewings (Figure 9A). The maximum under grade (60\%) was observed for beans that have undergone no brewing (Figure 9A). This corresponding to the lowest proportion of successes (Figure 9B). Therefore, no brewing can apparently having a detrimental impact on the quality of merchantable cocoa. The highest proportion of successes is more than $96 \%$ which is obtained by one brewing. 

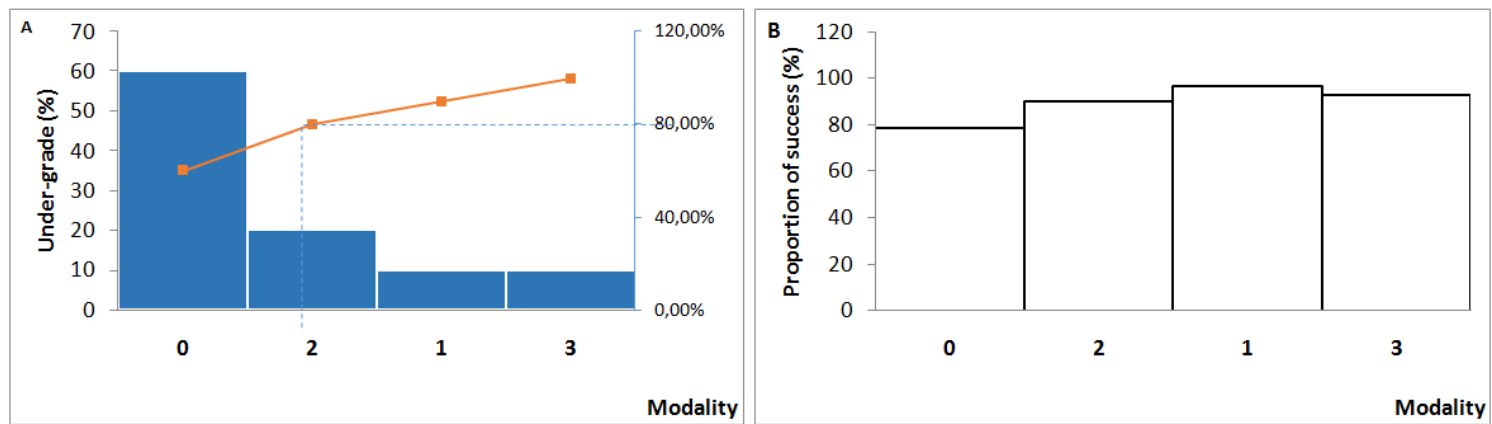

Figure 9. Number of brewing (A: Pareto chart for modalities; B: Proportion of successes )

\subsubsection{Identification of the Fermentation Time Causing Non-quality}

Fermentation times ranging from 2 to 5 days provide $80 \%$ of the total of samples in under grade (Figure 10A). The proportions of successes for these modalities are 24\%; 75\%; $49 \%$ and $93 \%$ for $2 ; 3 ; 1$ and 5 days respectively (Figure 10B). Among them, the fermentation times of 1,2 and 3 days which have given the lowest percentages of success, help to lower the quality of merchantable cocoa.
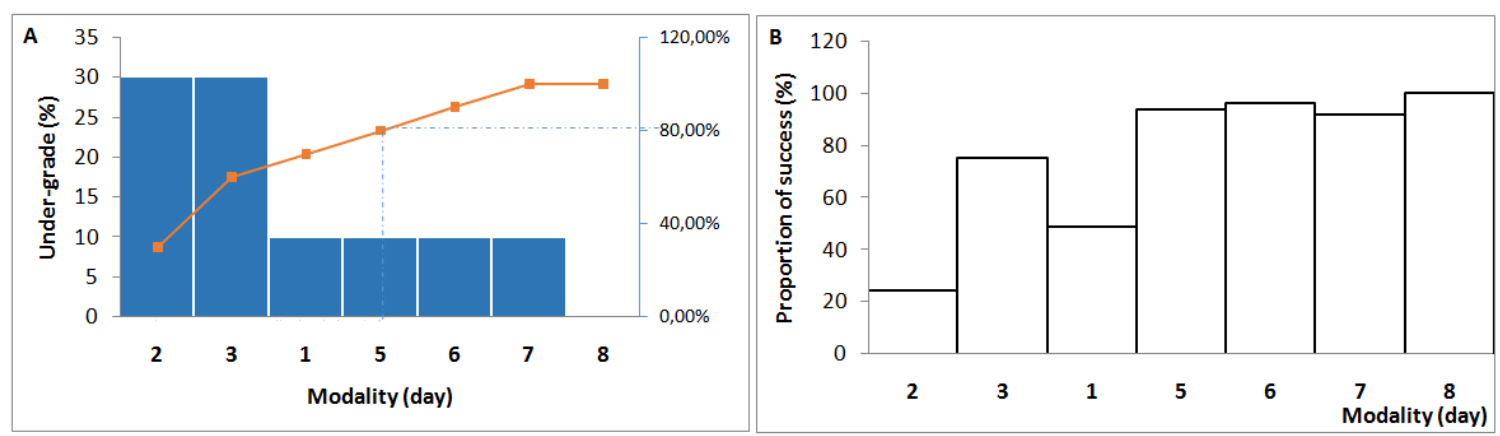

Figure 10. Fermentation time (A: Pareto chart for modalities; B: Proportion of successes )

\subsubsection{Identification of Fermentation Materials Causing Non-quality}

Figure 11A shows that $90 \%$ of the total of samples in under grade were fermented with banana leaves $(50 \%)$ and black plastic films (40\%). However, the proportion of successes of each of these materials remains above $80 \%$ (Figure 11B). Unlike the latter, nylon sheeting provide 10\% of the total of samples in under grade with $97 \%$ success in his use.

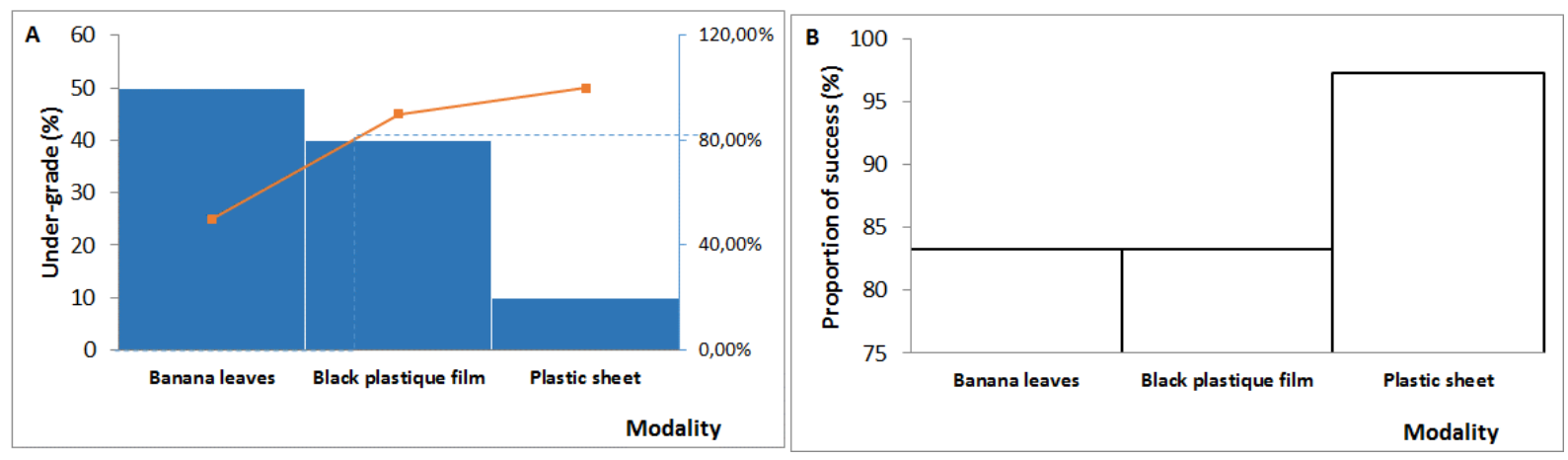

Figure 11. Fermentation mterials (A: Pareto chart for modalities; B: Proportion of successes )

\subsubsection{Identification of the Drying Time Causing Non-quality}

The modalities of drying times less than or equal to 6 days provide $80 \%$ of the total of samples in under grade (Figure 12A). The other twenty percent of the total under grades are from modalities of 7 and 8 days. No samples in under grade was observed at 10 day. Apart from the modalities of drying times of 2 (0\% success) and 3 (74\% success) days, all drying times applied have higher success to $80 \%$ (Figure 12B). 

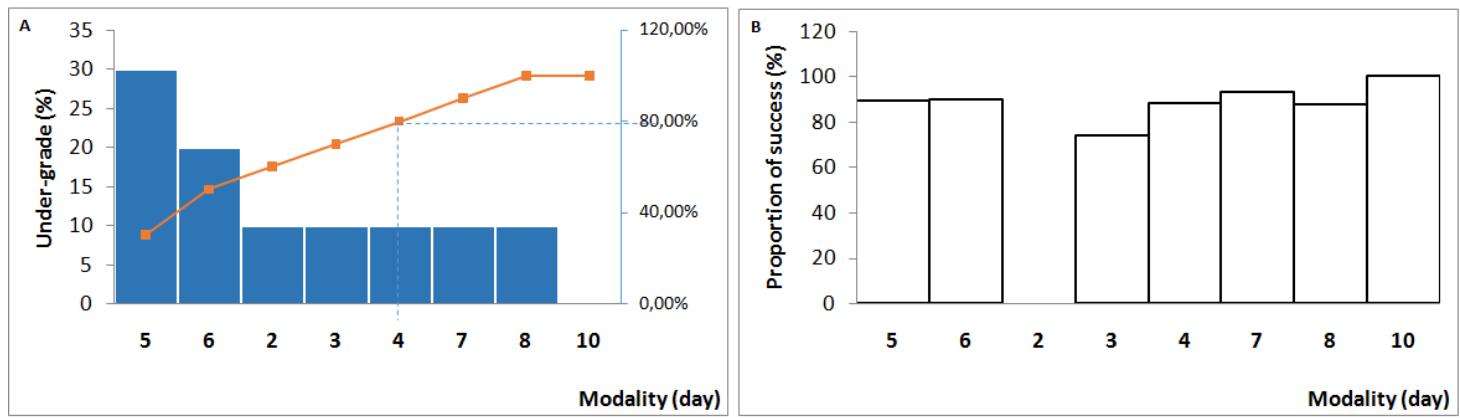

Figure 12. Drying time (A: Pareto chart for modalities; B: Proportion of successes )

\subsubsection{Identification of Drying Materials Causing Non-quality}

Drying materials such as nylon tarp and black plastic film represent $80 \%$ of the total of samples in under grade against $20 \%$ from the cemented area and drying rack (Figure 13A). The lowest proportion of successes $(88 \%)$ is observed in the use of black plastic. Drying rack and cemented area gave respectively $97 \%$ and $94 \%$ of success in their use.
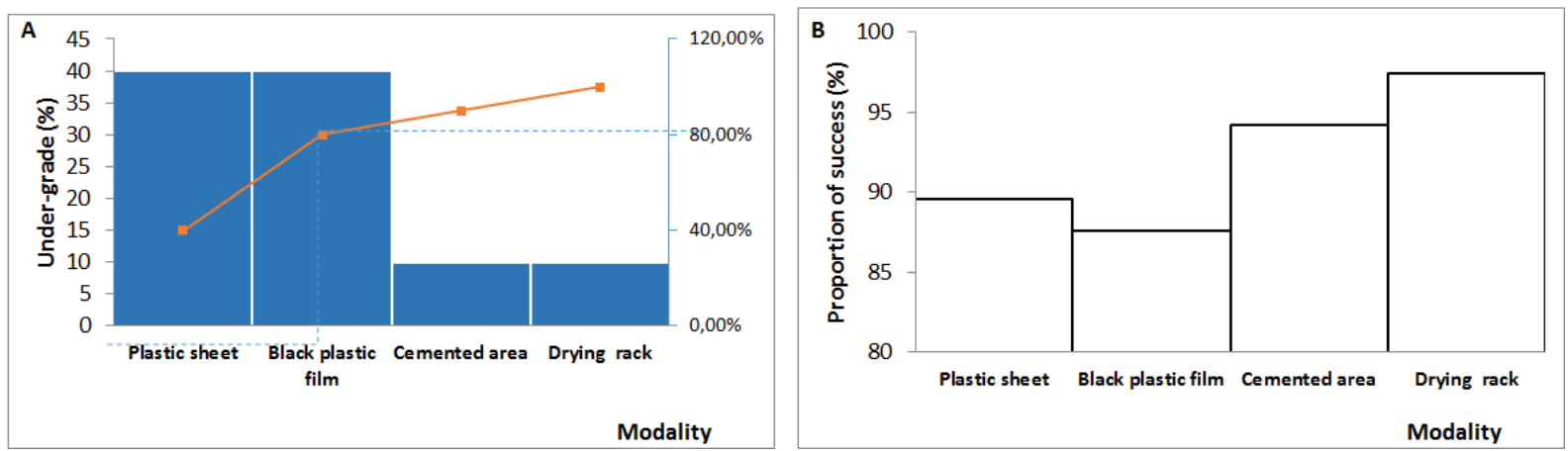

Figure 13. Drying materials (A: Pareto chart for modalities; B: Proportion of successes )

\subsection{Discussion}

According to the chi square tests, the comparison of post-harvest practices shows that apart from the time of pods breaking and drying time, post-harvest practices are inconsistent significantly between individual farmers and farmers in cooperative. We can assume that within the modalities of breaking pods and drying time, the producers have similar reactions in the face of the constraints of such practices. At the level of time of pods breaking, these constraints could be due to the limited need for labour that is the same in all areas of production. Because harvest and breaking pods can not be achieve only by the farmer. Because harvest and breaking pods can not be achieve only by the farmer. At the level of drying time, the constraints are related to climatic factors (sunshine, humidity) that may adversely the drying, regardless of the action of producers. In this study the times collected have varied from 3 to 10 days. In some areas, drying may last up to three weeks (Barel, 2013). The influence of the seasons of year on the drying of cocoa beans Côte d'Ivoire was mentioned by Akmel (2010).

Very high significant differences between the two groups of producers, were observed in the number of brewing; in the fermentation time; materials of fermentation and drying. Concerning the modalities of brewing, the most applied were 2 and 3 among farmers in cooperative (69\%) and no brewing among individual farmers (52\%). This could be due the fact that unlike farmers in cooperatives, individual farmers are not trained in good post-harvest practices and don't understand the usefulness of brewing during fermentation (Anonymous, 2006). Indeed, the brewing permit more air to get into the cocoa so that the rate of fermentation increase and temperatures will go up a few hours later (AusAid, 2010). This operation encourage the formation of a range of acetic bacteria which is crucial to ensure a good fermentation.(Cros, \& Jeanjean, 1995). The lack of training is also observed on the recommended time of fermentation (4 and 7 days) (Cros, \& Jeanjean, 1995). Individual farmers take less time in the fermentation that farmers in cooperatives. According Barel (2013) and others (Anonymous, 2000), to make a good cocoa, fermentation must stop between 5 and 7 days for the Forastero variety. This recommendation is followed by $95 \%$ of the farmers in cooperative against $66 \%$ of the individual 
farmers. There may be a risk of insufficient fermentation in the case of individual farmers. Regarding fermentation materials, $65 \%$ of farmers in cooperative have used of the banana leaves against $27 \%$ among individual farmers. They prefer to use other materials (black plastic film and nylon tarp) due to lack of banana leaves that seem to be the most recommended material for fermentation (Cruz, Troude, Griffon \& Hébert, 1988; Anonymous, 2000).

Regarding the drying materials, individual farmers have used different materials from those used by the farmers in cooperative. Indeed the drying racks (recommended drying material) were used by $32 \%$ of the farmers in cooperative and have been increasingly abandoned among individual farmers (3\%). However, the user rate of drying racks remains low (17.5\%) of producers as a whole. This is due to the fact that according to the majority of farmers, it is very difficult to find the raffia bamboo (plant family Arecaceae) to manufacture the drying racks. For this reason, other materials were preferred over the drying racks.

Regarding the modalities of the post-harvest practice responsible of the under-grades and their proportion of successes, the results showed that the samples of farmers in cooperatives had fewer defects than those of individual farmers. This is evidence that farmers in cooperatives are better trained and coordinate better the modalities of post-harvest practices for quality. In addition, the results showed that most of the modalities can lead to under-grade beans and they have different proportions of success. This is explained by the fact that quality can not depend on a single modality but it depends on a good combination of the modalities of the post-harvest practices.

At the level of time breaking pods, the modality of one day must not to be encouraged because it gave poor results, unlike other methods, which the number of success remained above $80 \%$. The tendency to decrease in under-grade with increasing of time breaking pods is consistent with the literature. Indeed, delay the time for the breaking of pods is always advantageous. Water loss during storage of pods reduces about $50 \%$ the quantity of juice and promotes better aeration during fermentation, which accelerates the temperature rise and thus fermentation (Barel, 1987). However, some authors recommend not to exceed 5 or 6 days to prevent the germination of beans, their decay or the appearance of foreign tastes (Mossu 1990; Barel, 2013).

At the level of number of brewing, the maximum under-grade (60\%) was observed for the cocoa beans which have not undergone any brewing. This result may be due to the lack of individual farmers awareness concerning the brewing. The modality with a single brewing is encouraging (96\% success) especially for the heap fermentations. Indeed, for the fermentation most of ivorians farmers carry out the heap fermentations. This type of fermentation is simplest of all and does not require a farmer to have to construct fermentation boxes (AusAID, 2010). According Barel (2013) under these conditions, the number of brewing can be reduced to one or two. But for box fermentations, two to three brewings are needed for proper fermentation.

At the level of fermentation times, durations of less than five days must be not encouraged because they represented more than $70 \%$ of all the total of under- grades. These durations may be responsible for an insufficient fermentation. For the modalities longer than or equal 5 days there were over $90 \%$ of success on each modality. However for good fermentation 5 to 7 days are required depending on the size of the fermenting cocoa mass (Mossu, 1990; Anonymous, 2000; Barel 2013). At the level of fermentation materials, the fact that the banana leaves have the proportion of under-grade relatively high could be due to unavailability or a bad combination of this material with other modalities non-compliant. For indeed banana leaves are the most recommended (AusAID, 2010). Nylon tarps are very successful in their use it may due to good control of these farmers who find them more available.

At the level of fermentation materials, the fact that the banana leaves have the proportion of under-grade relatively high could be due to unavailability or a bad combination of this material with other modalities non-compliant. For indeed banana leaves are the most used (Lainé, 2001; AusAID, 2010). Nylon tarps are becoming popular, the reason is the good control of this material by the farmers who find them more available.

At the level of drying of materials, even if all the materials are very successful in their use, the drying rack and the cemented area is largely characterized by a relatively small proportion of under-grade. Among both materials, the drying rack has an advantage because air can flow horizontally and vertically through the cocoa beans that are spread on the rack out in the sun. There is at this level more convective heat exchange between the air and the product. Moreover, in the early hours of drying, the too wet beans $(50-60 \% \mathrm{wb})$ can sometimes drip off through the racks without the retaining of the water on its surface, which does is not the case for non-perforated materials such as cemented area (Akmel, 2010; Barel, 2013). 


\section{Conclusion}

The comparison of post-harvest practices shows that there is no correlation between individual farmers and farmers in cooperative. Highly significant differences ( $p$-value $<0.001$ ) between the two groups of producers have been observed in the number of brewing; the time of fermentation; the materials of fermentation and drying. These differences have confirmed that post-harvest practices have an impact on the quality of merchantable cocoa. The samples collected from farmers in cooperative have under well defects than those of individual farmers. Regarding the modalities of post-harvest practice responsible of under-gade, the results show that most of conditions can lead to the under-grades. And these modalities have different proportions of success. Thus, in order to achieve a production of high quality cocoa, farmers must do a good combination of each recommended modality. However certain modality should be avoided. These are: the time breaking pods of one day; the absence of brewing during the fermentation; the time of fermentation less than or equal to three days and the time of drying less than or equal to two days.

\section{Acknowledjements}

This study was possible thanks to the support of leaders of ICRAF (International Centre for Research in Agroforestry) Côte d'Ivoire.

\section{References}

Akmel, D. C. (2010). Séchage solaire des fèves de cacao : Etude expérimentale et modélisation de la cinétique de séchage. Thèse unique de l'Université d'Abobo Adjamé, Abidjan, Côte d'Ivoire.

Anonymous. (2000). De l'école lenôtre: Chocolat et confiserie, Tome 1. Ed. Jerôme villette, De Agostini, Milan, pp 13-16. Retrieved from

http://c3d.94.free.fr/ebooks/Desserts/Chocolats\%20et\%20Confisserie\%20-Tome\%201\%20-\%20Ecole\%20L enotre.pdf

Anonymous. (2006). Elaboration d'un plan national café cacao : étude diagnostic. Bourse du café et du cacao (BCC). Abidjan, 60.

Anonymous. (2010). Chocolat : 3 entreprises (Cemoi, Blommer et Petra Food) familiales et internationales s'inussent pour développer une filière éthique et de qualite en Côte d'Ivoire. ADOCOM, Dossier de presse, Paris, 7 pages.

Anonymous. (2015). Bilan de la réforme de la filière café-cacao. Journées nationales du cacao et du chocolat, Octobre 2015, Yamoussoukro-Côte d'ivoire, pp 1-20

Anonymous. (2016). Côte d'ivoire: inquiétudes redoublées autour de la qualité des fèves de cacao. Jeune Afrique. Retrieved from http://www.jeuneafrique.com/332225/economie/cote-divoire-inquietudes-autour-de-qualite-feves-de-cacao/

AusAid. (2010). Cocoa processing methods for the production of high quality cocoa in Vietnam. Retrieved from www.canacacao.org/uploads/smartsection/19_Cocoa_fermentation_manual_Vietnam.pdf

Banzio, D., (2003). Comprendre et operer dans les filières café cacao en dix modules. Ed. Eburnie; Abidjan, Côte d'Ivoire, 10-23.

Barel, M. (1987). Délai d'écabossage: Influence sur les rendements et la qualité du cacao marchand et du cacao torréfié. 31.

Barel, M. (2013). Qualité du cacao : impact du traitement post-récolte. Ed. Quae, Savoir faire, 104 p.

Guehi, T. S., Dingkuhn M., Clément-Vidal, A., Cros, E., Fourny, G., Ratomahenina, R., \& Moulin, G. (2005). Détermination de l'origine de l'activité enzymatique impliquée dans la formation des acides libres du cacao. Cirad-Agritrop, 14th International Cocoa Research Conference. Lagos: Cocoa Producers' Alliance, 869-873. Retrieved from http://catalogue-bibliotheques.cirad.fr/cgi-bin/koha/opac-detail.pl?biblionumber=193229

International trade centre [UNCTAD/WTO], (2001). Cocoa: Commercial Practices Guide. Ed : Genève: UNCTAD/WTO, cop. Vol. XI, 190.

Cros, E., \& Jeanjean, N., (1995). Cocoa quality: effect of fermentation and drying. CIRAD-CP, Montpellier, France, 24. Retrieved from www. agritrop.cirad.fr/387560/1/document_387560.pdf

Cruz, J. F., Troude, F., Griffon, D., \& Hébert J. P. (1988). Conservation des grains en régions chaudes-2. ed.«Techniques rurales en Afrique». Paris, France, Ministère de la Coopération et du Développement, 542. Retrieved from http://www.fao.org/Wairdocs/x5164F/X5164f00.htm 
Janny, G. M., Ritchie, B. J., \& Flood, J. (2003). A la découverte du cacao. Un Guide pour la formation des facilitateurs, $1-50$.

Koko, L. (2014). Teractiv Cacao as a New Fertilizer based Reactive Phosphate Rock for Cocoa Productivity in Côte d'Ivoire: A Participatory Approach to Update Fertilization Recommendation. Procedia Engineering, 83, 348-353. http://dx.doi.org/10.1016/j.proeng.2014.09.14.

Lainé, K. (2001). Enquête sur les pratiques culturales dans les cacaoyères en Côte d'Ivoire 29 Octobre-10 Novembre 2001 Projet PACCC / ICCO / Industrie sur l' amélioration de la qualité du cacao en Côte d' Ivoire. Rapport. (pp. 1-27).

Levai, L. D., Meriki, H. D., Adiobo, A., Awa-Mengi, S., \& Akoachere, J. F. (2015). Postharvest practices and farmers' perception of cocoa bean quality in Cameroon. Agriculture \& Food Security, 4, 28. http://dx.doi.org/10.1186/s40066-015-0047-z

Mossu, G. (1990). Le cacaoyer. Editions Maisonneuve et Larousse. 159. Retrieved from www.ecofog.gf/giec/doc_num.php?explnum_id=774

Mounjouen, P., Gueule, D., Ntoupka, M., Durand, N., Fontana-Tachon, A. Guyot, B., \& Guirand, J. (2011). Influence of post-harvest processing on ochratoxin A content in cocoa and on consumer exposure in Cameroon. World Mycotoxin Journal, 4(2), 141-146. http://dx.doi.org/10.3920/WMJ2010.1255

\section{Copyrights}

Copyright for this article is retained by the author(s), with first publication rights granted to the journal.

This is an open-access article distributed under the terms and conditions of the Creative Commons Attribution license (http://creativecommons.org/licenses/by/4.0/). 